\title{
ODKAZ MUSORGSKÉHO BORISE GODUNOVA V DRAMATU SMUTA ARSENIJE A. GOLENIŠČEVA-KUTUZOVA
}

\author{
The Influence of Mussorgsky's Boris Godunov on the Play \\ Smuta by Arseny A. Golenishchev-Kutuzov
}

Keywords: Boris Godunov, Mussorgsky, drama Smuta, Arseny Arkadyevich Golenishchev-Kutuzov, Russian drama

Contact: Masarykova univerzita; dupalova.zuzana@email.cz

Opera Boris Godunov Modesta Petroviče Musorgského (1839-1881) je dnes již světoznámým hudebním dílem, jehož význam tkví nejen v tom, že představuje jedinou operu, kterou tento geniální skladatel Mocné hrstky kompletně dokončil, ale především ve faktu, že se jedná o první operu napsanou na čistě prozaické libreto, jež si pro své dílo si napsal Musorgskij sám. ${ }^{1}$ Právě pod vlivem této opery napsal Musorgského př́tel Arsenij Arkad’jevič Goleniščev-Kutuzov svou dramatickou kroniku Smuta (1879). Následující stránky zachycují spojitosti mezi hlavními postavami dramatických děl Musorgského a Goleniščeva-Kutuzova, tj. mezi Borisem Godunovem a Vasilijem Šujským, a nahlíženy jsou také rozdíly v pojetí role národa s cílem dokázat, že opera Boris Godunov měla vedle vlivu hudebního i vliv literární.

Arsenij Arkad’jevič Goleniščev-Kutuzov (1848-1913) byl ruský básník, prozaik, dramatik a publicista, vystudoval práva a v sedmdesátých letech publikoval své básně

\footnotetext{
${ }^{1}$ Inspirací mu byla dvě významná ruská literární díla - Dějiny ruského státu Nikolaje M. Karamzina a Puškinovo drama Boris Godunov (1825). První verze opery (1869) byla komisí Mariinského divadla odmítnuta, údajně pro nedostatek výrazných ženských postav, Musorgskij pak Godunova přepracoval a druhá verze již byla přijata. Premiéra díla se konala pod taktovkou Eduarda Nápravníka v petrohradském Mariinském divadle 27. ledna / 8. února 1874. Puškin a Musorgskij nebyli však jedinými, kdo se chopil historické látky doby Smuty. Lžidimitrijovská tematika byla především v 19. století v Rusku dramatiky velmi oblíbená a často zpracovávaná. Události z počátku 17. století, kdy se mladý dobrodruh s nejasným původem vydává za dávno mrtvého syna Ivana Hrozného Dimitrije, aby dosáhl ruského trůnu a sesadil nezákonného cara Borise Godunova, a který nakonec sám skončil zabit, poskytovaly vše potřebné pro poutavý příběh, včetně milostné zápletky. Kromě Puškina svá dramata na toto téma napsali např. Alexandr Ostrovskij (Дмитрий Самозванец и Василий Шуйский, 1867) Alexej Tolstoj (Царь Борис, 1870) nebo Alexej Chomjakov (Дмитрий Самозванец, 1833), ještě před Puškinem např́klad Alexandr Sumarokov (Димитрий Самозванец, 1771), věhlasu Musorgského opery a Puškinova dramatu se však žádné z ruských děl nevyrovnalo. Téma se v dlouhém 19. století výrazně projevilo i v Německu, kde se významnou inspirací pro ostatní tamní spisovatele stala nedokončená dramata Friedricha Schillera a Christiana Friedricha Hebbela.
} 
v žurnálech Дело а Вестник Европы. Přátelil se s hudebním kritikem Vladimirem V. Stasovem a s jeho pomocí roku 1875 vydal poemu Гашиш, která pronikla do širšího povědomí. Jeho vrcholné básnické umění představují např́íklad sbírky Затишье и буря (1878), Стихотворения (1884, 1901, 1912) а На закате (1912), které v mnohém souzněly s díly ruských symbolistů. Jeho básně se dočkaly častého zhudebnění (jeho texty podložili hudbou např. Kjuj, Ljapunov, Nápravník, Rachmaninov), osudovým se mu však stalo přátelství s Modestem P. Musorgským, který na jeho básně napsal dva písňové cykly (Bez slunce 1874, Písně a tance smrti 1875-77), baladu Забытый (1874) nebo romans Видение (1877). Goleniščev-Kutuzov se stal také autorem libreta Musorgského nedokončené opery Soročinský jarmark. Dramatickou kroniku Smuta (1879), která je předmětem zájmu tohoto příspěvku a kterou, jak již bylo zmíněno, napsal básník pod vlivem Borise Godunova, tomuto skladateli dedikoval (Николаев 1989: 603-604).

\section{Pojetí hlavních postav}

Drama Smuta v pěti jednáních Arsenije A. Goleniščeva-Kutuzova nepatří mezi nejslavnější díla zabývající se tímto tématem (Lžidimitrij navíc vystupuje pouze v prvních dvou jednáních), ovšem svou návazností na Musorgského operu je poměrně zajímavé. Děj začíná chvíli poté, kde Musorgského (i Puškinovo) dílo končí, hostinou na oslavu Samozvance, poslední scéna pak zobrazuje př́ichod zajatce Vasilije Šujského na dvůr polského krále. ${ }^{2}$ V Musorgského opeře hlavní úloha připadá Godunovovi, v Kutuzovově dramatu stojí v popředí díla ctižádostivý Šujskij, kterého s operním Borisem mnoho nespojuje. Boris je váhavý a důstojný státník zkroušený nečistým svědomím s krví careviče Dimitrije na svých rukách, Šujskij využije každé příležitosti, aby posílil svou moc, a neštítí se úskoků a lží, intrik se vzdává až přijetím koruny.

\footnotetext{
${ }^{2}$ Samozvanec Dimitrij je upozorněn na Šujského komploty proti němu, Šujskij je zatčen a poslán do vyhnanství do Galiče, po nějaké době ho ale Dimitrij povolává zpět do Moskvy, Šujskij s návratem neváhá a chystá se carovi zasadit konečnou ránu. Po svém návratu si Šujskij obratným jednáním s Marfou, matkou mrtvého careviče Dimitrije, která nyní předstírá, že je i matkou samozvancovou, zajistí Marfin př́slib, že po chystaném převratu před lidem dosvědčí, že car Dimitrij nebyl jejím skutečným synem. Na začátku třetího jednání se kupec Fjodor Koněv chystá s druhy na povstání vedené Šujským, je zachyceno škorpení a nedočkavost tlupy, začátek bouře je odstartován zvoněním zvonů. Po úspěšném povstání se Šujskij chystá, že se stane novým carem. Za nového cara je skutečně zvolen on. Další děj se odehrává až na sklonku Šujského vlády, skrze konverzaci šlechtičny s mladou cařicí se dozvídáme o nepokojích na Rusi i o novém, již druhém samozvanci se jménem Dimitrije. Šujskij po svém př́ichodu vyjevuje, že nechápe vývoj událostí, přichází jeho bratr s varováním, že se lid srocuje a bouří, Šujskij odchází povstalcům hrdě vstříc. Je nucen vzdát se koruny. Ctižádostivá Marina, manželka prvního Lžidimitrije, nyní předstírá, že svého manžela poznala v novém samozvanci, ale náhle se dozvídá, že její muž byl na lovu zabit, a Marina je tím ztracena. Poslední scéna dramatu se odehrává v Polsku na královském dvoře, kam je přiveden jako zajatec Šujskij, ten je stále hrdý, král se smiluje a nechává starého Rusa v klidu dožít v domácím vězení na panství. Jak je vidět, děj je podobně jako i u Musorgského opery velmi roztříštěný a je nutná obeznámenost čtenáře nebo publika s historickými událostmi.
} 
Hned první Šujského monolog v dramatu (1. akt, 1. scéna) připomíná Borisův první monolog opery (prolog, 2. scéna). ${ }^{3}$ Zatímco u Borise jde o korunovační řeč, Šujskij po hostině se samozvancem přemýšlí o budoucnosti:

Musorgskij

БОРИС ГОДУНОВ

Скорбит душа.

Какой-то страх невольный

зловещим предчувствием

сковал мне сердце.

О праведник, о мой отец державный!

Воззри с небес на слезы верных слуг

и ниспошли ты мне

священное на власть благословенье.

Да буду благ и праведен, как ты, да в славе правлю свой народ!

Теперь поклонимся почиющим властителям Русии.

А там сзывать народ на пир, всех, от бояр до нищего слепца!

всем вольный вход, все гости дорогие!

Goleniščev-Kutuzov

ШУЙСКІЙ

Сбираются надъ головою тучи,

Быть, быть грозъ!... Посмотримъ, чья возьметъ!

Сдается мнъ, до сей поры не даромъ

Господь меня храниль святой десницей,

Въ годину бъдъ, и милостью своей

Запечатльль главу мою сьдую.

(...)

Исчезнеть лживый призракъ, аки дымъ,

И свято мъсто снова пусто станетъ!

Ктожь мъсто то заиметь? Господь всесильный!

Не помяни гръховъ моихъ великихъ,

Дай силу мнъ на подвигъ многотрудный,

Змъиную мнъ мудрость дай, чтобъ могъ

Враговъ моихъ я сокрушить злодьйство!

(...)

Oba monology, či spíše jejich začátky (u Borise první čtyři řádky, u Šujského první dva), spojuje pocit blížícího se nebezpečí - Borise svírá zlá předtucha, Šujskij tuší

\footnotetext{
${ }^{3}$ Texty z opery jsou převzaty z edice Borise Godunova od Davida Lloyda-Jonese z r. 1975 (Mussorgsky 1975), texty dramatu z vydání z roku 1879 (Голенищев-Кутузов 1879).
} 
nějakou převratnou událost, „bouři““, u které si ale není jist, na čí hlavu se snese. Boris následně prosí o Boží požehnání pro svou vládu - oproti tomu Šujskij je si vědom jakési ochrany, kterou mu Bůh do té doby poskytoval. Šujskij si je jist, že po úspěšném převratu se uvolní místo na trůnu a již si na něj myslí sám. Boris pak Boha prosí o vlastnosti jako je dobrota a spravedlnost, Šujskij o sílu na „hrdinství" a lstivou moudrost. $V$ těchto monolozích je již poznat základní rozdíl mezi oběma postavami: je třeba zde zmínit, že tato část Borisova monologu je niterná, není určena pro uši ostatních, což jí dodává na pravdivosti. Musorgskij se sice při psaní tohoto monologu nechal inspirovat Puškinovým Borisem a jeho korunovačním monologem, ten ale působí mnohem formálněji a strojeněji právě díky tomu, že je celý adresován patriarchovi a bojarům. Zatímco Godunov se obává budoucnosti, Šujskij ji očekává s netrpělivostí, zatímco Boris chce být spravedlivým vládcem, Šujskij se snaží přemoci své nepřátele, kteř́ jsou v jeho očích zároveň nepřáteli Rusi.

Zároveň je nasnadě, pokud mluvíme o Godunovově korunovačním monologu, jej porovnat s korunovační řečí Šujského v dramatu (3. obraz 3. dějství):

Musorgskij

БОРИС ГОДУНОВ

Скорбит душа.

Какой-то страх невольный

зловещим предчувствием

сковал мне сердце.

О праведник, о мой отец державный!

Воззри с небес на слезы верных слуг

и ниспошли ты мне

священное на власть благословенье.

Да буду благ и праведен, как ты, да в славе правлю свой народ!

Теперь поклонимся почиющим властителям Русии.

А там сзывать народ на пир, всех, от бояр до нищего слепца!

всем вольный вход, все гости дорогие!

\section{Goleniščev-Kutuzov}

ШУЙСКІЙ

Народъ московскій! Возблагодаримъ

Царя Небеснаго за избавленье

Отъ смутъ и бъдъ, ниспосланныхъ на насъ.

Свидътельп Богъ - я не искалъ престола.

Служа Руси, себя я забывалъ.

Въ тяжелую годину испытаній 
Я слезы лиль сь народомъ, и молитвы

Ко Господу смиренно возносиль,

Да отвратить Онъ бъдствія отчизны,

Да дасть ей миръ, и счастіе, и славу,

И мудраго правителя. Теперь

Хотите вы. чтобъ я пріяль державу,

И на престолъ царей московскихъ сьль?

Противиться и спорить не дерзаю,

Склоняюся предъ божьимъ повельньемъ

И волей всей Руси. - Да будетъ такъ!

Jedním z hlavních rozdílů mezi monology je ten, že Šujského proslov je určen lidu. Na rozdíl od Godunova, který má zlé tušení, zde Šujskij děkuje za konec těžkých časů, čehož, jak víme, se Rus ještě několik let nedočkala. Zároveň se zapřísahá, že trůn nechtěl a vždy trpěl společněs Rusí. Nyní, když si ho lid vyvolil, se neopovažuje protivit jeho a Boží vưli a svůj úkol pokorně přijímá. Tento proslov by mohl působit upřímně, pokud bychom však $\mathrm{v}$ jeho monologu přímo předcházejícím korunovační scéně nebyli svědky toho, jak dychtivě očekává, že novým vládcem bude zvolen právě on, a jak se snaží ještě naposledy působit skromně a pokorně, aby si nezprotivil bojary a Boha.

Největší podobnost mezi Smutou a Musorgského operou ale nacházíme v jedné celé scéně, a to v prvním obraze čtvrtého dějství dramatu, které se silně podobá pátému obrazu opery. V opeře na začátku pláče Borisova dcera Xenie nad mrtvým snoubencem, vchází Godunov a nachází potěšení v rozpravě se synem Fjodorem, přichází ovšem Šujskij, který mu sdělí zprávu o osobě samozvance vydávajícího se za careviče Dimitrije, na konci scény se Borisovi v šílenství zjevuje př́zrak mrtvého Dimitrije. Tato scéna byla výrazně dotčena přepracováním opery, vyličený základní děj však zůstává stejný. Začátek čtvrtého dějství dramatu se odehrává na sklonku Šujského vlády. Ve své komnatě si jeho žena povídá se starou šlechtičnou, která jí informuje o nepokojích na Rusi, kde se zjevil druhý Lžidimitrij, který se vydává za svého předchůdce, navíc je lid nespokojen s Šujského vládnutím. Přichází podrážděný car, jeho žena ho uklidní, vchází ovšem jeho bratr, který velel výpravě proti Lžidimitriji II., a zpravuje ho, že zrádci začali ve velkém přecházet na stranu samozvance, lid se srocuje a bouří se. Manželce se sice podaří cara znovu uklidnit, ale vzápětí si Šujskij uvědomí nebezpečí vzpoury a skutečně je slyšet zvonění zvonů (které jako znamení začátku vzpoury použil i on sám proti Lžidimitriji I.). Přichází bojaři, aby mu dali zprávu o povstání vedené bojarem Ljapunovem a car vychází vzbouřenému lidu hrdě vstř́íc.

V obou dílech tyto scény začínají bez prítomnosti cara v pokoji jejich milovaných, následně přichází car, který právě se svými blízkými (synem nebo nevěstou) nachází útěchu, $\mathrm{v}$ obou dílech mají carové monolog (viz dále) vyjevující jejich 
strasti s vládou. V dramatu i v opeře je z rozhovoru vyruší Šujskij - v opeře jde o bojara Vasilije, budoucího cara, v dramatu o jeho bratra. V opeře Šujskij předá Godunovovi zprávu o tažení samozvance pod jménem Dimitrije, v dramatu carův bratr promluví o zradách a přeběhlících ke Lžidimitriji II. a bouření lidu. V obou dílech se car $\mathrm{k}$ narušiteli chová $\mathrm{s}$ opovržením a nedůvěrou. Ke konci obou scén mají oba carové záchvat paranoii, Boris vidí ducha mrtvého chlapce, Šujskij si uvědomí nebezpečí vzpoury a slyší neexistující křik, poté ale skutečně zazvoní zvon jako znamení povstání. Co se týče monologů obou carů, jejich podobnost je zjevná - ani jeden z carů nevládne v klidu, Boris si úpadek Rusi vysvětluje jako trest za své hř́chy, Šujskij ale nechápe, proč ho Bůh trestá. $\mathrm{V}$ obou monolozích je $\mathrm{v}$ závěru též naznačena nespokojenost s chováním lidu, který se od svých carů odvrací:

\section{Musorgskij \\ БОРИС \\ Достиг я высшей власти, шестой уж год я царствую спокойно; но счастья нет моей измученной душе. Напрасно мне кудесники сулят дни долгие, дни власти безмятежной.}

Ни жизнь, ни власть, ни славы обольщенье, ни клики толпы меня не веселят;

В семье своей я мнил найти отраду, Готовил дочери веселый брачный пир, Моей царевне, голубке чистой. Как буря, смерть уносит жениха... Тяжка десница грозного судии, Ужасен приговор душе преступной...

Окрест лишь тьма и мрак непроглядны! Хотя мелькнул бы луч отрады!

И скорбью сердце полно, Тоскует, томится дух усталый. Какой-то трепет тайный... Все ждешь чего-то... Молитвой теплой, к угодникам Божьим, я мнил заглушить души страданья...

В величьу и блеске власти безграничной, Руси владыка, я слез просил мне в утешенье...

А там донос: бояр крамола, Козни Литвы, и тайные подкопы, Глад и мор, и трус, и разоренье... Словно дикий зверь рыщет зачумленный; Голодная, бедная стонет Русь... И в лютом горе, ниспосланном Богом, За тяжкий наш грех в испытанье, Виной всех зол меня нарекают, 
Клянут на площадях имя Бориса!

И даже сон бежит, и в сумраке ночи

Дитя окровавленное встает... (...)

\section{Goleniščev-Kutuzov}

ШУЙСКІЙ

Покоя нътъ! Мнъ не даютъ

Покоя. Думалъ я, вступивъ на царство:

Теперь конецъ иевзгодамъ, треволненьямъ!

Я счастьемъ наслажусь... и позабыль, Что отнимать враги то счастье стануть! Казалось мнъ: смятенье, звонъ набата, Мятежъ бояръ, народа буйный кликъ,Все это я творю своею волей.

Все такъ и быть должно, пока на царствђ Сидитъ татаринъ, злой цареубійца, Иль мной-же впущенный въ Москву, бродяга Безъ племени и рода... Я ошибся! Потомокъ Рюрика, Москвы любимецъ, Народомъ избраиный, пріялъ вьнецъ И властвуетъ, - а Русь объята смутой! Кого еще ей надо? Или мало Лилася кровь? Иль Богомъ предназначенъ Иной Руси владыка! Гдъже онъ? Пусть явится, помърится со мною Заслугой, доблестью, иль честнымъ родомъ. Кто выше насъ, царица, покажи?! (...)

Чего имъ надо?

Разстрига смерть пріяль! Предъ всей Москвой Лежало тъло. Всъ надъ нимъ ругались, Благословляя Бога и меня...

И вдругъ молва: опять возсталъ изъ мертвыхъ Димитрій! И толпой къ нему бъгутъ, Надъ вымысломъ нельпымъ потъшаясь! БЪгутъ... Зачъмъ? Куда? На зло кому? Никто не въдаетъ. А царь одинъ, Что щепка на волнахъ!...

\section{Pojetí národa}

Problematika národa bývá obecně v mnoha lžidimitrijovských dílech výrazná např́íklad Puškin právě národ a obavu z jeho náhlého povstání přesunul do hlavního 
motivu svého dramatu Boris Godunov. Musorgskij ve své opeře roli národa oproti Puškinovi ještě posílil, nejvíce skličujícím okamžikem celé opery je závěrečná kromská scéna, kde se lid chová jako neúprosná lítá zvěř, která se krutě vysmívá polapenému carskému bojarovi. Právě tato scéna ale měla být předmět zklamání samotného skladatele. Podle vzpomínek Goleniščeva-Kutuzova se mu Musorgskij svěřil, že si vyčítá, že ruský lid zde vylíčil nepravdivě. Národ zabíjí a trestá, ale nikdy se svým obětem nevysmívá: «В этом акте, - ответил мне Мусоргский, - я, и притом единственный раз в своей жизни налгал на русский народ. Издевательства народа над боярином - это неправда, это нерусская черта. Рассвирепевший народ убивает и казнит, но не издевается над своей жертвой» (cit. dle Тюлин 1970: 93). Тato vzpomínka však byla mnohokrát, i v citovaném textu, napadnuta jako neprůkazná a tendenční. Její věrohodnost však nyní můžeme nechat stranou, jelikož zásadní je pro tento př́ispěvek způsob, jakým sám Goleniščev-Kutuzov s postavením národa ve své dramatické kronice nakládal a nakolik se držel vzoru Musorgského. Dramatik zařadil hned několik scén, kde hrají výraznou roli představitelé lidu. ${ }^{4}$

Nejvíce se i na základě zobrazených událostí sobě podobají scény korunovační, (1. scéna prologu opery a 3. obraz 3. dějství dramatu), v obou dílech je dění komentováno členy lidu, avšak zatímco v opeře lid řeší své osobní problémy a neprojevuje o politiku velký zájem, ve Smutě se lidé baví o politických záležitostech:

\author{
Musorgskij \\ ПЕРВАЯ ГРУППА \\ Митюх, а Митюх, чево орем? \\ МИТЮХА \\ Вона! Почем я знаю! \\ ВТОРАЯ ГРУППА \\ Царя на Руси хотим поставить! \\ ЧАСТЬ ЖЕНЩИН \\ Ой, лихонько! Совсем охрипла! \\ Голубка, соседушка, \\ не припасла ль водицы? \\ ДРУГАЯ ЧАСТЬ ЖЕНЩИН \\ Вишь, боярыня какая! \\ Орала пуще всех, сама б и припасала!
}

\footnotetext{
${ }^{4}$ První scéna druhého jednání se odehrává v domě kupce Soloda, který se dozvídá, že jeho přátelství se sousedem Šujským není politicky vhodné, Šujskij pak toká se Solodovou dcerou, dovídá se ale náhle o milosti od cara a chvátá zpět do Moskvy. První scéna třetího jednání zobrazuje kupce Fjodora a jeho tlupu, která se chystá k povstání pod vedením Šujského, její členové mezi sebou vtipkují i se sváří a scéna končí pobodáním jednoho z nich. Třetí scéna tohoto jednání se odehrává během oznámení, že se carem stává Šujskij, někteř́ jsou ale z této volby nadšeni o poznání méně než jiní. Druhá scéna pátého jednání nás zavádí k domu Lžidimitrije II., popisuje znesvářené skupinky osob a zlovůli kozáků, poslední scéna dramatu se potom odehrává v polském královském paláci, kde se polští šlechtici a šlechtičny mezi sebou různě škorpí, tato scéna tedy nezobrazuje ruský lid, ale má lidový charakter.
} 


\section{МУЖЧНИЫ}

Ну вы, бабы, не гуторить!

ЖЕНЩИНЫ

А ты что за указчик!

Вишь пристав навязался!

МИТЮХА

Ой, вы, ведьмы, не бушуйте!

Goleniščev-Kutuzov

ПЕРВЫЙ

Чего здъсь ждуть?

ВТОРОЙ

Аль сь неба, брать, свалился?

Сейчась царя Москва провозгласить!

Въ палатахъ думу думають бояре...

Ръшенья ждемъ.

ТРЕТІЙ

Когото изберутъ?

ВТОРОЙ

Въстимо, князя Шуйскаго!

Нъсколько голосов

Когоже, Какъ не его!

ЧЕТВЕРТЫЙ

Эхъ, братцы, право, любо!

Гляди, опять почнутъ въ колокола

Звонить на всю Москву, и пиръ горой

Пойдетъ, какъ въ день Борисова избранья.

ТРЕТІЙ

Теперь не до пировг!

ЧЕТВЕРТЫЙ

А что?

ТРТЕТІЙ

Да смута!

Какъ съ ляхамито справимся, Богъ въсть!

Немало ихъ намедни положили!

Войны не миновать...

Krvelačné vyznění Musorgského kromské scény zde nechybí - touha po prolití nenáviděné polské krve se objevuje ve scéně z domu kupce Fjodora, avšak např́klad právě onen „problematický“ výsměch můžeme nalézt v závěrečné polské scéně, kde se šlechtici vysmívají Mniszkovi kvůli jeho dceři Marině, manželce samozvanců, Goleniščev-Kutuzov se tedy tímto neprovinil proti ruskému prostému lidu, ale tuto krutost přiřkl polské šlechtě, která je $\mathrm{v}$ jeho podání povrchní, znuděná a hašteřivá. 


\section{Závěr}

Rozdíl mezi Borisem a Šujským je znatelný hned od počátku, kdy první jejich monology jsou v podstatě kontrastní. Zatímco Musorgskij v opeře podtrhl Godunovovo lidství (i v porovnání s Puškinovým dramatem), Šujského život jako by byl až do okamžiku jeho zvolení spjat pouze s politikou, což je i naznačeno např. ve scéně z vyhnanství, kdy ve chvíli, kdy je mu nabídnuto vrátit se zpět do Moskvy, se naprosto odvrací od počínajícího milostného vztahu i od svých předešlých slov, podle kterých by nově nabytý klid už nevyměnil za labyrint politického centra. Jeho povaha $\mathrm{v}$ dramatu do okamžiku korunovace je tedy shodná s negativní lstivou povahou Šujského, kterou nám předkládá Musorgskij ve své opeře. Po jeho korunovaci nastává v Šujského životě obrat - podle svých slov se vzdal úskoků, aby důstojně vládl svému lidu, a právě scéna z komnat jeho ženy naznačuje, že se povahově mnohem více přiblížil Borisovi, možná tímto autor naznačil i svůj pohled na charakter Borise před začátkem jeho vlády. V závěru je pro Šujského ale zásadní jeho nezlomná hrdost a důstojnost, kterou Boris svým šílenstvím i smrtí na scéně ztratil. Šujského postava tedy není zdaleka tolik rozervaná jako Godunov v opeře, vždy u něj dominuje jediný povahový rys. V tomto ohledu je více než s Musorgského Godunovem srovnatelný s Borisem z Puškinova dramatu. Po Puškinově vzoru Musorgskij udělal z lidu ústřední subjekt a hlavní konflikt postavil mezi lid a šlechtu s panovníkem, lid v jeho pojetí prochází vývojem z bezduché masy do revoluční síly. Významná role lidu v dějinách je naznačena i GoleniščevemKutuzovem - jak víme, byl to lid, díky kterému mohl Lžidimitrij I. usednout na trůn, vylíčeno je zde, jak právě i kvůli lidu padl, Šujskij se stává carem s podporou lidu, nespokojenost lidu je ale zároveň to, co zapř́činí konec i jeho vlády a vzestup Lžidimitrije II., lid je tedy př́tomen v každé scéně, kde se odehrávají zlomové okamžiky dramatu. Goleniščev-Kutuzov tímto ukazuje, že úspěch vlády závisí právě na podpoře lidu, který je ale vrtkavý a divoký. Paradoxem je, že Šujskij v jeho podání využíval právě těchto vlastností lidu při svržení Lžidimitrije, neuvědomil si ale, že se může lid obrátit i proti němu, zákonnému carovi, což je patrné v jeho citovaném monologu. V pojetí lidu i v zobrazení hlavních postav tedy lze nalézt shody, a to ve sféře ideové i v rovině textové, jak bylo dokázáno na doložených ukázkách. Podrobnější srovnání či komparace dalších jednajících postav by byla jistě zajímavá, avšak již toto relativně zběžné porovnání dokázalo, že Goleniščev-Kutuzov byl Borisem Godunovem ovlivněn nejen v oblasti výběru tématu svého dramatu, ale také v jeho naplnění. 


\section{Summary}

This paper deals with the theme of the influence of the opera Boris Godunov by M. P. Mussorgky on the drama Smuta by A. A. Golenishchev-Kutuzov, Mussorgsky's friend. In the paper the connections between the main characters (Godunov and Vasili Shuisky) and in the conception of the nation are analysed. Golenishchev-Kutuzov was clearly influenced by the opera and some moments of his play bear a strong resemblance to the scenes of Boris Godunov, the role of the people in the history as outlined in the drama is similar to the role of the nation in the opera.

\section{Literatura}

Mussorgsky, M. P. Boris Godunov: Opera in four Acts with a Prologue. Lloyd-Jones, D. (ed.), 2 vols. London: Oxford University Press, 1975.

Голенищев-Кутузов, А.А. Смута. Драматическая хроника в пяти действиях. Санкт-Петербург, 1879.

Николаева, Л.А. Голенищев-Кутузов, Арсений Аркадяевич. In: Николаев, Л.А. (ред.) Русские писатели 1800-1919. Биографический словарь. Том 1. Москва: Советская энциклопедия, 1989, с. 603-604.

Тюлин, Ю. К изучению наследия М.П. Мусоргского. Сцена под Кромами в драматургии Бориса Годунова. In: Тюлин, Ю., Фрид, Э., Ярустовский, Б., Кандинский, А., Аравон, П. К изучению наследия М.П. Мусоргского. Сцена под Кромами в драматургии Бориса Годунова. Советская музыка. 1970 (34/3), c. 90-98. 